Final draft of paper subsequently published as:

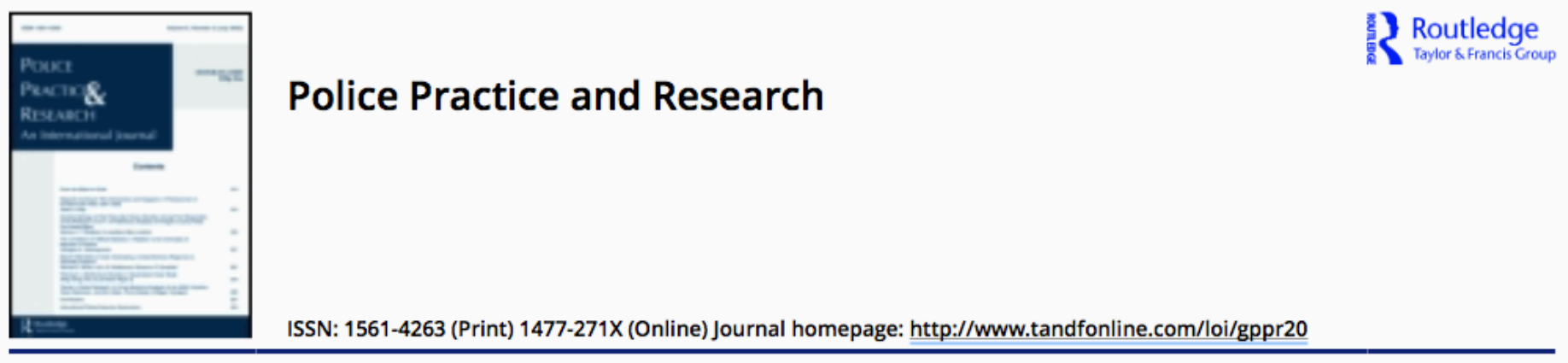

\title{
Who should the police be? Finding a new narrative for community policing in South Africa
}

\author{
Monique Marks , Clifford Shearing \& Jennifer Wood \\ To cite this article: Monique Marks, Clifford Shearing \& Jennifer Wood (2009) Who should the \\ police be? Finding a new narrative for community policing in South Africa, Police Practice and \\ Research, 10:2, 145-155, DOI: 10.1080/15614260802264560
}

To link to this article: http://dx.doi.org/10.1080/15614260802264560

\begin{abstract}
In South Africa, police cling to the idea of a policing monopoly and prove reluctant to exhaust possibilities for sharing the load of creating safety. Nevertheless, they operate knowing that feelings of insecurity are rising and diverse 'nodes' for governing security have been established. Police and public authorities realize that a policing monopoly is more a dream than a reality, yet their policies and practices surrounding partnerships reveal an incoherent vision. We argue that this incoherence provides opportunities for designing innovative partnerships for the nodal governance of security that support the notion of a 'core,' and publicly symbolic police role.
\end{abstract}




\section{Introduction}

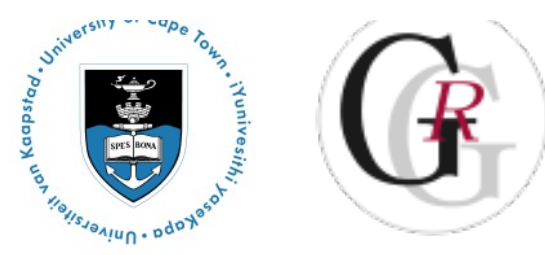

Since at least the inception of the 'community policing' movement, public police organizations around the world have been on a quest to re-think both their roles and their relationships with non-state groupings. Re-imagining policing has been a very difficult task. On the one hand, police desire to maintain what they view as their established monopoly of the policing enterprise, while at the same time, and often in very instrumental ways, they use the language of partnerships and problem-solving to devolve responsibility for sticky and thorny security problems to civic and private groupings.

The tensions and ambiguities that the public police feel about their current place in the world are evident in a broad narrative they express through their policy statements, media presentations, and public commitments. In this paper we examine this narrative, focusing on the contradiction it reveals between a police dream of realizing a monopoly over policing and the erosion of this monopoly through the (re)emergence or perhaps (re)assertion of other governmental nodes engaged in policing. We suggest that the dream of a monopoly of policing by police is no longer a viable or credible dream and that police should begin to look for another source of inspiration.

We endeavor to provide a new imagining of 'community policing,' one that moves beyond an understanding of the police as all things to all people, an agency that will do almost anything to (re)gain legitimacy and to be at the centre of all governance problems (see, for example, Skogan, 2007). We advance rather a 'minimalist' conception of the police, one that centers on clarifying, articulating, and bolstering their unique authority and capacities. We contend that within a 'nodal policing' framework, this conception provides new opportunities for recognizing and harnessing the unique forms of knowledge and capabilities that other nodes can bring to bear in the governance of security. In essence, we seek to join forces with the police in their questioning of their own role as well as the place of other security actors in an age of polycentric, nodal security governance.

\section{The established police narrative in post-apartheid South Africa}

In both established and transitional societies, the organizational field of policing is now characterized by a range 'nodes' or institutional actors with variable structures, legal status, resources, mentalities, and technologies (Dupont, 2006, p. 86). It is now broadly accepted by government actors (including the police) that the demand for security exceeds the capacity of the government to provide it (Wood, 2006b). This acceptance may be reluctant, but there is a basic appreciation that a more nodal or 'networked' approach to governing security provides potential for greater effectiveness and a broader reach in service delivery (Rhodes, 2006).

South Africa is often cited as an 'ideal type' of pluralization. It has one of the fastest growing - in size and influence - private security industries in the world (Berg, 2007). Further, there has been for some time now a wide range of non-state policing initiatives, particularly at the 
local level. These include street committees organized by politicized

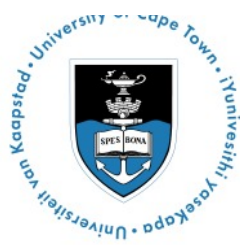

youth, traditional courts usually run by community elders, and neighborhood patrols and watches (see, for example, Brogden \& Shearing, 1993; Dixon, 2000; Roche, 2002). In short, a fair amount of social ordering in South Africa has occurred in spite of the state (see Schärf \& Nina, 2001).

Notwithstanding such developments, the public police have not wished to recede into the background (see Dupont, 2006, p. 88). This impulse is not peculiar to South Africa. Police throughout the world do speak of and generally advocate, partnerships, but such talk is not the result of a coherent state governance project. Nor is it indicative of a state in retreat. Rather, as Garland has observed elsewhere, governments and state agencies '[tend] to combine responsibilisation moves with measures intended to consolidate central power, directing the actions of others, more or less coercively, to bring them into line with centrally defined goals' (Garland, 1996, p. 464). In South Africa, we find a fluid, fragmented, and ambiguous state policing framework which, if anything, is geared toward increasing the reach of the public police.

Policing policy in South Africa does emphasize partnerships. The term 'community policing' was first formally used in 1997 when the Department of Safety and Security published its formal policy document entitled 'Community Policing Policy Framework and Guidelines' (Pelser, 1999). In this text, community policing is presented as a collaborative partnershipbased approach to (local level) problem-solving. Its logic is based on an acknowledgement that the objectives of the police can only be achieved through a collaborative effort of the police with other government organizations, structures of civil society, and the private sector (see Pelser, Schnetler, \& Louw, 2002). An added, and perhaps unique, impetus in the South African case for embracing community policing was a commitment on the part of the new 'democratic' government to bottom-up governance and to civic participation. These practices had a strong legacy in South African society, particularly within the anti-apartheid/liberation movement.

A community policing narrative remains central to South African Police Service (SAPS) policy documents and is an integral part of their basic training programs. But just as is the case in other parts of the world, it has become focused almost entirely on ways of mobilizing nonstate actors to legitimize and increase the effectiveness of the police. Contrary to early conceptualizations of community policing in post-apartheid South Africa, there is presently no real support for 'counter-hegemonic policing initiatives' (Dixon, 2000, p. 17) or for lateral partnerships. Talk about partnerships is limited to conventional notions of the community assisting the police through providing information and supporting public policing initiatives (see, for example, Cachalia, 2007).

Over the past 10 years, new police narratives have emerged that now overshadow talk of community-oriented, collaborative problem-solving policing. As crime and fear of crime reached crisis levels in the 1990s, the language and strategies of police ministers and commissioners 'became more aggressive ... the new thinking emphasised cordon-and-search operations in which whole city blocks were closed down, doors were kicked in and anyone 
suspicious was taken in for questioning' (Altbeker, 2007, p. 31).

What we have witnessed is a remilitarization of police discourse (see Cachalia, 2007; Dixon, 2000). This trend is reflected in the continual increase of public police budgets, ongoing commitments to increases in police numbers, and an almost exclusive focus on traditional indirect indicators of police performance (Bayley, 1994) such as numbers of arrests and weapons seized (Newham, 2005; Rauch, 2002).

The dominant police narrative in South Africa now resounds with statements about police needing to assert their authority and their dominant role within policing networks. Instead of the public police speaking about the decentralization of policing resources (a central component of community policing), police leaders now want to centralize public policing resources. The National Commissioner of the SAPS recently announced plans to incorporate city and municipal police into a single South African Police Service. In his view, centralizing resources will increase the effectiveness and efficiency of the police through a shared system of line functions and accountability.

The police and their political authorities acknowledge that the public police are unable to meet even the most basic policing needs. Yet, there are no clear mechanisms or structures for mobilizing policing resources outside of the state. Where the idea of 'partnerships' is actually used, it mostly refers to joint working arrangements with private security companies, not with civil society groupings. Arguably, this is partly due to the fact that police see private security companies as their 'natural' allies and partners.

The relationship between the public police and private security officers is not always harmonious. There are disagreements about turf, strategy, knowledge flow, and lines of accountability. Yet, there is, in some ways, a shared cultural affinity between private and public police officers (Singh \& Kempa, 2007). In a public statement, the Minister of Safety and Security declared that 'government is considering a ground breaking plan to rope in the country's 300,000 strong army of private security guards to help the police fight crime.' His proposed plan is to establish an 'upgraded partnership' with security companies that 'satisfy legal requirements' so they can be called upon in 'emergency situations' (see Sekoana, 2007). Exactly how this 'upgraded partnership' will work, remains to be seen.

In August 2007, the Minister of Safety and Security announced that 'security guards could soon be securing crime scenes, reporting suspect vehicles and listening in to police crime alerts' (Philip, 2007). The minister announced that this would be part of a project called Project Griffin, a project design imported from the UK as a plan to fight terrorism with joined up public and private police resources. The Griffin system trains private security officers to spot criminals and to 'man' crime scenes supposedly to 'free police to do police work' (Philip, 2007). Security guards participate in weekly police briefings via conference calls, which focus on the identification of individual suspects and hot spots to keep an eye on or look out for. This piloting of Project Griffin has already begun in two police districts - one in Johannesburg and one in Cape Town.

While private security partnerships appear to be the focal point of public police narratives, police leaders have made recent statements about the need to mobilize community members 
in the fight against crime. South African police policy frameworks

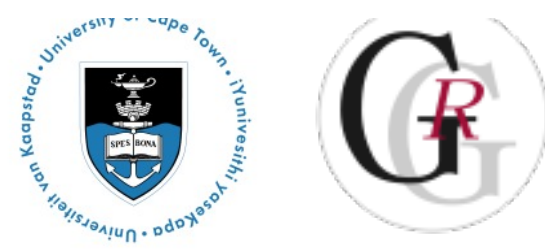

have shifted fairly significantly since the transition to democracy in 1994. Initial policy frameworks such as the 1994 Interim Constitution were framed by broader post-apartheid governmental commitments to citizen participation (see Gordon, 2006). Newly elected government officials and policy makers were keen to incorporate communitarian ideals into new policies. The idea in these early days of democracy was for the new democratic state to loosen its monopolistic hold of law and order and to put in place mechanisms for the coproduction of security. The Interim Constitution (unlike anywhere else in the world) provided for the establishment of community policing forums in two ways: firstly, enabling consultation and fostering the legitimacy of the police at the local level, and secondly, getting local communities more engaged in local security governance solutions. The 1996 National Crime Prevention Strategy (NCPS) also spoke to the importance of community policing partnerships and multi-agency approaches to the problems of crime and insecurity (Rauch \& van der Spuy, 2007; Singh, 1997).

Yet, even in these early years of democratic government, there were signs that commitments to public empowerment were shaky. As Gordon puts it: 'The pool of shared idealism that conceived of justice as co-produced by state and citizen was shallow, and officials of the formal system were ... reluctant to concede control over resources or authority to nonprofessionals who had recently been their antagonists' (2006, p. 216). It is not surprising, then, that we have witnessed a significant shift in national police policy, most evidenced in the 1998 White Paper on Safety and Security. This policy document focuses on ways of making the police more effective law enforcers (Newham, 2005; Rauch, 2002) and is no doubt partly a response to public outcries about high levels of crime and pressure for the state to deal more decisively with this problem.

Paul Graham, Director of the largest non-government organization in South Africa, the Institute of Democracy in South Africa (IDASA), suggests that the shift away from community engagement both on the part of state and non-state actors is understandable. In his view, 'after the intensity of engagement through the transition, the police revert to uniform type and civil society actors move on to the job of life ... Citizens increasingly see themselves as clients or customers' (Graham, 2007).

Despite the public police conundrum about high crime levels and limited state resources, they are unwilling to 'let go' of what they see as traditional (and very broad) police functions. For Graham, in reviewing this truism in South Africa, the police's monopolizing tendency needs to be understood within a specific (national) political, social, and historical context. Graham posits:

... the police find it particularly difficult to engage constructively with civil society actors. The necessary internal cohesion and hierarchy combines with the uniform to create a self-reliant and closed institution ... Further, the conflict prior to and during a transition will inevitably have resulted in the police taking a particular view of civil society actors and engaging them in particular ways - as enemies or informers, as prisoners or perpetrators, or as a stumbling block or impediment to police action. $(2007$, p. 3$)$ 
We do not doubt Graham's wisdom, but feel that this cultural

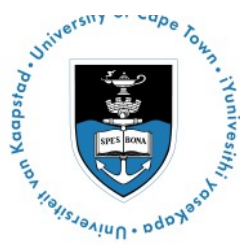

obstacle is perhaps an inevitable result of the police holding onto their monopolization dream and their inability to imagine what a more diverse and complex (and much messier) policing matrix may look like.

South African criminologists Dirk van Zyl Smit and Elrena van der Spuy have also tried to take stock of the hold that the state strives to retain over the authorization and provision of policing services. In their view,

... it is true that in South Africa, as elsewhere in the transitional world, reform of policing in its widest sense has been reduced to a much narrower reorganisation of law enforcement. The grand alliance of state, market and civil society in pursuit of the 'governance of security' (Shaw and Shearing 1998), as originally anticipated, has failed to materialise. The integration of informal justice and policing structure with the formal machinery of state control has made almost no headway. (2004, p. 202)

Buur, Jensen, and Stepputat (2007) suggest that this state re-monopolization has occurred in other parts of Southern Africa that have emerged from protracted liberation struggles. They make the following interesting argument:

On the one hand, states do not necessarily exercise a monopoly of violence, while on the other hand the particular histories of liberation struggles have created forms of resistance, ideas concerning threats to the national unity of which liberation movements claim to be the sole guardians and a political ethos of monism that makes the separation between state, party and government hard to identify. Instead, ambiguous figures of popular sovereignty exercise power derived from an alleged history of political resistance. This form of power often sits uncomfortably with the operation of the new constitutional democracies: whereas constitutional democracy sees political order as being derived from the constitution, it involves consuming and legally taming the political energies that made its creation possible in the first place. (p. 13)

Non-state, more informal groupings, in this view, are perceived as threatening to security, rather than as contributors to it. But the desire from the center to hold onto security governance also results from an awareness (and anxiety) on the part of policy makers and state agency leaders that if the 'new' democratic government is unable to deliver on the provision of basic services it is likely to face a crisis of authority and legitimacy. A loss of confidence in the government's capacity to respond to people's need for security may have a dramatic impact on democratic values and engagement (Marks \& Goldsmith, 2006; Smit \& Botha, 1990).

This desire by the public police to re-imagine policing as their 'exclusive domain' (Australian Police Professional Standards Council, cited in Wood, 2006a, p. 260) has been recognized as an international phenomenon (see Gordon, 2006). Studies of policing in places like Australia and the UK show that the public police are still trying to find ways of asserting their primacy. In Australia the police and their unions are doing this by asserting how indispensable they are as 'professionals' in the policing field (see Fleming, Marks, \& Wood, 2006; Wood, 2006b). In England and Wales police leaders have responded to pluralization of policing by trying to 
extend the police family at the 'intra-organisational level' rather

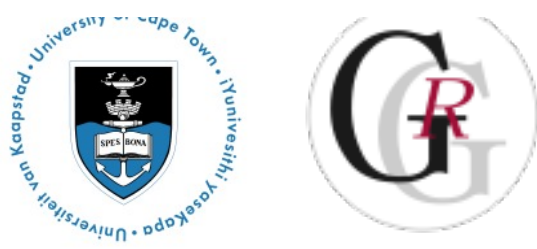
than the 'inter-organisational level' (Johnston, 2007, p. 135). But regardless of these attempts to monopolize, policing governance remains pluralized with the various players viewing themselves and others as (in varying degrees) significant or irrelevant players. The sticking point is that the ways in which these various players view themselves and each other may not align. There is also a lack of clarity about the identities and roles of nodal players.

This role confusion, combined with strong directives and close monitoring from the center has had very worrying consequences. It has resulted in limited possibilities (and support) for local innovation and responsiveness. It has created the space for private companies with a very narrow set of interests to take over a range of traditionally public police roles. But, more positively, it also generates gaps or spaces for thinking more carefully about what the police should be doing, who they are, and what the 'community policing' project now means.

\section{Who should the police be?}

The question of who the police are and should be is one that is receiving considerable attention in South Africa, a country which stands out as having the highest levels of violent crime in the world. In a recently published book, Altbeker (2007) argues that instead of seeing South Africa as a 'society in transition,' we should view it as a 'half-made' society. What he pessimistically argues (by his own admission) is that the lack of a clear strategy for making South Africa safer has meant that we cannot assume that South Africa is a society in transition. This phrase, he says, suggests that there is some well thought through plan of action geared towards a better end-state. This is seriously lacking in South Africa where policing policy is contextually inappropriate, police officers lack direction, and walls between people (literally and figuratively) are getting higher.

What is urgently required in South Africa, Altbeker argues, is 'a state that can protect its citizens from the more dangerous of their compatriots' (2007, p. 180). This demands a corps of police who, first and foremost, can prove themselves able to 'find, prosecute and incarcerate criminals' (p. 137). What we require is 'institutions that draw firm lines in the sand and then come down heavily on people who cross those lines' (p. 146). In Altbeker's view, we must shift away from what he considers 'the absurd idea' that police officers are the 'fulcrum around which the reengineering of society would turn' (p. 140).

While Altbeker's perspective may be controversial, it is certainly not new. Indeed, the left realist school of criminology in Britain has argued for some time that a 'minimalist policing approach' is the most appropriate way forward. By this they mean that for the police to be effective and accountable to the law, 'police intervention should be confined to cases where there is clear evidence of law-breaking, and then should take the form of the invocation of legal powers and criminal process' (Reiner, 1992, p. 145). In other words, instead of widening the reach of the police, we need to confine them to what they are trained and resourced to do and what interventions they are inclined toward.

The police, policing scholars, and the public need to be clear about what the core 
competencies and functions of the public police are.

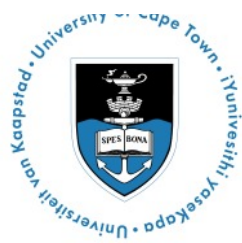

Simultaneously, it is important to have a firm understanding about which security governance functions should be 'outsourced' to non-state agencies that hold resources or legitimacy that the police do not have in providing a range of security services (see Wood, 2006a). In countries like South Africa, and more especially in those where states are very weak or governance happens in spite of government, the need for this kind of delineation is even more pressing.

Good security governance requires strong and distinguishable policing nodes. For this to occur, all parties in networked arrangements need to be clear about what it is they can individually contribute and what they can realistically expect from the public police (Brogden \& Shearing, 1993). Only once this is achieved will the public police move away from ad hoc and instrumental (sometimes exploitative) approaches to partnerships. And it is only then possible for non-state actors to be clear about what to expect from the public police and where their own interventions begin and end. It will, in short, allow for a formally agreed upon 'negotiated division of labour' (Menkhaus, 2007, p. 106) between policing nodes.

This would allow the police to get on with what they know best and to prove their effectiveness as a key agency within emergent or transitional states. This would provide a basis for certainty about who precisely does what, how, and at what cost. The result, hopefully, would be a state-building exercise that harmonizes state authority with local systems. Such an approach, Menkhaus argues, is the 'best hope for achieving something remotely approaching effective governance in communities desperate for a more predictable and secure environment' $(2007$, p. 108). What is least desirable are arrangements that perpetuate half-made societies.

In thinking about core functions of the public police, it is important to first consider what is unique about the role of the public police. Two suggestions can be made when considering this unique role. Firstly, while the police no longer hold the monopoly over the legitimate use of force, they remain unique in their specialized training to use ubiquitous coercion in a graduated and discretionary way. Secondly, the police remain a fundamental representative of the legal system (Reiss \& Bordua, 1967, p. 27) and through their presence demonstrate that a 'regime of law exists' (Bayley, 1994, p. 34). Because of this, and because of their capacity to curtail individual freedoms in the most dramatic ways, the police are able to intervene authoritatively to restore order (Bayley, 1994), resolve conflict, control crowds, and curtail (rather than prevent) crime. The police, in this model, would distinctly outline actual functions that they feel they are uniquely placed to do because of this established role.

If the functions of the police were more clearly delineated, this would make institutions and mechanisms of accountability far simpler to design. Trusting relationships would be built through a much deeper sense partnership, where the role of each contributing partner is recognized, supported, and respected. In addition, the surest way to build legitimacy on the part of the police is for them to demonstrate their effectiveness in their core function. Once the public police are clear about their own role, and feel less pressured to respond to an everwidening demand for their interventions, a space will be created to actively encourage and 
even to learn from alternative (non-state) ways of social ordering.

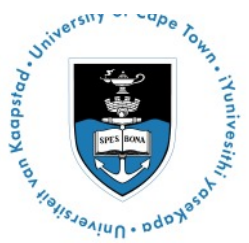

This is important because these local, non-state forms of ordering usually enjoy a high degree of legitimacy and local ownership and their solutions to everyday security problems are often more effective than 'inorganic, top-down' state interventions (Menkhaus, 2007).

One advantage of this perspective on who the police should be is that it fits well with what the police want to be. They want to be 'real police' who can intervene effectively to combat crime, to restore public disorder, and to hold (at least symbolically) the 'big gun' (Bjork, 2006). They don't want to be stretched beyond their capacities in terms of their resources, their training, their mandate, or their skills base. In developing countries like South Africa, they simply cannot be the hub of all community/societal problem-solving that is linked to broad notions of security.

\section{Community policing principles for emergent and post-conflict states}

It may seem that what is being suggested represents a retreat from 'community policing,' a step backward towards 'professional,' disassociated policing. To the contrary, we are trying to explore ways of making community policing work better and to avoid a situation where people in places like South Africa throw up their hands and say that it is simply a failed colonial import. We also want to move beyond a community policing narrative that the police own and control, toward a model that accounts for police limitations and the range of alternative policing sources that are already out there. The voices denouncing community policing have already become very loud in South Africa. For instance, some skeptics see it as a model that is too all-embracing and nefarious for countries struggling with basic governance issues (see Altbeker, 2007; Burger, 2007).

Community policing should be centered on the creation of horizontal and vertical matrixes between the police and other groupings involved in governing security. It should be about mobilizing as many resources and capacities as possible in making communities safer. It is about joining forces to create a political environment in which citizens feel safe to demonstrate dissent and to engage in peaceful social conflict. For these principles to be actualized, the police must be clear about their core role. They need to be confident in the knowledge that they have a unique right, and requisite skills to use legal bureaucratic violence with discretion to resolve conflicts and create social order (Bjork, 2006).

While police ought to tell a clear and consistent story of who they are, they should encourage competing narratives of what both 'communities' should be as well as their roles in relation to their police partners. Having carved out a specific role and function for themselves, the police should be much better placed to identify roles that need to be filled by other groupings to make societies safer. The process of acknowledging their own limited ambit would encourage them to work collaboratively with other actors (both state and non-state) to fill security gaps. In such a system, each node - each strong and distinguishable from the other - would need to develop the capacity to broker (as a verb) to other nodes, or put another way, to enlist the unique capacities and resources of other nodes around a problem or need 
that requires those special resources.

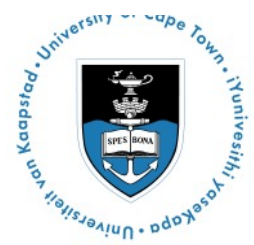

Community policing is about bringing the state closer to civil society in co-producing security. The idea of partnership is at the center of community policing, as is the task of problemsolving. There is no one model for what such a vision of community policing will look like. There is no one-size fits all solution. We need to allow for a certain degree of messiness and diversity. What is required is experimentation based on what resources are available locally and nationally, variable political and social historical trajectories and, perhaps most importantly, the reality of what it is that states are able to offer in an effective and accountable manner.

The coordinators of these systems, we suggest, should be local government who, together with the communities they 'govern,' would identify which security problems exist, which resources (state and non-state) are available to fill these gaps, and what systems of accountability would need to be put in place so that all sectors of diverse communities are equally guaranteed of security outcomes. They would need to think of creative ways to encourage participation and volunteerism. This would involve incentive planning both for those privately funded non-police security activities and for those who get their own hands dirty in creating safer living, working, and leisure spaces.

The police should be central to these locally coordinated government systems. In particular, they should have the unique responsibility of nurturing otherwise weak nodes (i.e., lacking in political, economic, or other forms of capital), even if that simply means: (a) acknowledging the unique abilities and resources of less resourced nodes; (b) allowing themselves to be enlisted by such nodes according to mutually agreed upon conditions/rules; (c) brokering traditionally weak nodes to other nodes so that the latter can leverage up their capacities and resources and become stronger by drawing on the strengths of others; (d) being more 'responsive' (Ayres \& Braithwaite, 1992) to the contributions that other nodes play, so that the specific interventions or roles of the public police are properly calibrated, and complimentary to, the work that other nodes do.

The role of the police as government actors would be to ensure that publicly agreed upon norms for policing are adhered to, that due process is upheld, and that justice is enacted when arrests are made. The public police would not monopolize policing but they would be key government actors that ensure and facilitate public safety and security. As Zedner puts it, the public police should play the central role of delineating and upholding the normative structures essential both to protect the public interest in policing and maintain the ligatures of civil society' (2006, p. 93). The onus on public police organizations would thus be to resource, skill-up, and train their officers to be knowledge brokers (Ericson, 1994), facilitators, and experts in the discretionary enforcement of law. Their role would be to ensure that force and the curtailment of freedoms is used effectively.

In addition to their 'brokering' function, police should promote and support strategic and joined-up problem-solving, particularly in preventing crime, so that a reversion to authoritarian, or command-and-control approaches to problem-solving are avoided and prisons do not prosper as homes of excluded populations (i.e., those that engage in petty 
crime or disorderly behavior or conduct unbecoming). What we

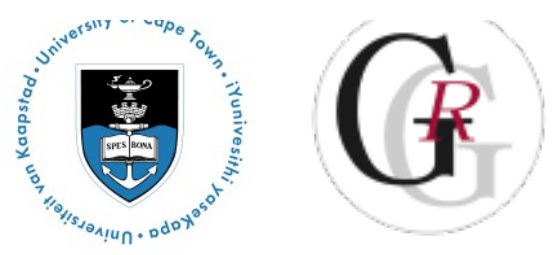
want in places like South Africa is certainty that serious crime will be dealt with effectively by the police. What we don't want is a society that is, to use Jonathan Simon's phrase (2007), exclusively 'governed through crime,' where criminals and the 'crime prone' are segregated into prisons and urban ghettos and where 'law abiding' citizens are sheltered in gated communities, patrolled shopping malls, and secure work places (Davis, 1990).

This approach to understanding who the police should be is consistent with the vision that Loader and Walker have recently advocated in their book, Civilizing Security (2007), where they argue for a role for the state as a guarantor of the public interest within a plural policing system.

\section{Conclusion}

It is perhaps old news to state that, contrary to the expectation that development, in the form of democratisation, would reduce levels of violence and enhance security, violence and crime seem to be multiplying, with the result that crime and violence have become political issues that states and governments have to take seriously. (Buur et al., 2007, p. 23)

In post-conflict, newly emerging democracies, states and their police are being (re-)fashioned. They are looking for secured roles for themselves as well as ways of reaching out to other actors to enhance security while concurrently building state legitimacy and effectiveness (Dupont, Grabosky \& Shearing, 2003).

Developing and weak states are in no position to have police officers that are expected to be community activists and generalist problem solvers. Rather, what is required is police who know what they should be doing and are given the space to do their job in the best way possible. This places a responsibility on national governments to develop clearer frameworks of core police functions and roles and to enable local government actors (like municipalities) to act as facilitators and coordinators.

The transitional nature of South African state and society means that configurations of policing may be somewhat different from those in more established liberal democracies. In transitional societies there is less regulatory capacity, a greater correspondence of actual crime with fear of crime, less certainty about the role of the state, and a weary (yet historically mobilized) civil society. But the debate about who should be doing what in policing and how this should be done is equally relevant to post-conflict, transitional, and established democratic societies (Johnston, 2000, p. 3).

\section{References}

Altbeker, A. (2007). A country at war with itself. Johannesburg: Jonathan Ball.

Australian Police Professional Standards Council (2006). Defining the Australian policing profession. Canberra, Australia. 
Ayres, I., \& Braithwaite, J. (1992). Responsive regulation:

Transcending the deregulation debate. New York: Oxford University Press.

Bayley, D.H. (1994). Police for the future. New York: Oxford University Press.

Berg, J. (2007). The accountability of South Africa's private security industry: Mechanisms of control and challenges to effective oversight. Cape Town: Criminal Justice Initiative of the Open Society Foundation for South Africa.

Bjork, M. (2006). Policing agonistic pluralism: Classical and contemporary thoughts on the viability of the polity. Distinktion, 12, 75-91.

Brogden, M., \& Shearing, C. (1993). Policing for a new South Africa. London: Routledge.

Burger, J. (2007). Strategic perspectives on crime and policing in South Africa. Pretoria: Van Schaik.

Buur, L., Jensen, S. and Stepputat, F. 2007. "The security development nexus". In The security development nexus: Expressions of sovereignty and securitization in Southern Africa, Edited by: Buur, L., Jensen, S. and Stepputat, F. 9-36. Cape Town: Human Science Research Council Press.

Cachalia, F. 2007. Operation Iron Fist after six months: Provincial police strategy under review. Crime and Quarterly, 19: 21-27.

Davis, M. 1990. City of quartz: Excavating the future of Los Angeles, New York: Vintage Books.

Dixon, B. 2000. The globalisation of democratic policing: Sector policing and zero tolerance in the new South Africa, (Occasional Paper Series) Cape Town: Institute of Criminology, University of Cape Town. Retrieved from http://web.uct.ac.za/depts/sjrp/publicat/global1.htm

Dupont, B. 2006. "Power struggles in the field of security: Implications for democratic transformation". In Democracy, security and the governance of security, Edited by: Wood, J. and Dupont, B. 86-110. Cambridge: Cambridge University Press.

Ericson, R. 1994. The division of expert knowledge in policing and security. British Journal of Sociology, 45(2): 149-175. 
Fleming, J., Marks, M. and Wood, J. 2006. Standing on the inside looking out: The significance of unions in networks of police governance. The Australian and New Zealand Journal of Criminology, 39(1): 71-89.

Garland, D. 1996. The limits of the sovereign state - Strategies of crime control in contemporary society. British Journal of Criminology, 36: 445-471.

Gordon, D. 2006. Transformation and trouble: Crime, justice and participation in a democratic South Africa, Ann Arbor: The University of Michigan Press.

Graham, P. 2007. Creating a civil society - The role of civil society organisations in security sector reform during political transitions. Paper presented to Interpol Heads of Training Symposium, Emperor's Palace. Johannesburg. March 6, 2007.

Johnston, L. 2000. Policing Britain: Risk, security and governance, Harlow: Pearson Education.

Johnston, L. 2007. 'Keeping the family together': Police community support officers and the 'police extended family' in London. Policing and Society, 17(2): 119-140.

Loader, I. and Walker, N. 2007. Civilizing security, Cambridge: Cambridge University Press.

Marks, M. and Goldsmith, A. 2006. "The state, the people and democratic policing: The case of South Africa". In Democracy, security and the governance of security, Edited by: Wood, J. and Dupont, B. 139-164. Cambridge: Cambridge University Press.

Menkhaus, K. 2007. Governance without government in Somalia: Spoilers, state building and the politics of coping. International Security, 31(3): 74-106.

Newham, G. . A decade of crime prevention in South Africa: From a national strategy to a local challenge. Research report written for the Centre for the Study of Violence and Reconciliation. Johannesburg. Retrieved from http://www.csvr.org.za/papers/papnwh17.htm

Pelser, E. 1999. The challenges of community policing in South Africa, Pretoria: Institute of Security Studies. (Occasional Paper No. 42)

Pelser, E., Schnetler, J. and Louw, A. 2002. Not everybody's business: Community policing in SAPS priority areas, Pretoria: Institute for Security Studies. (Monograph No. 72)

Philip, R. 2007. Security guards to partner police. Sunday Times, August 26 News Section

Rauch, J. 2002. "Changing step: Crime prevention policy in South Africa". In Crime prevention 
partnerships: Lessons from practice, Edited by: Pelser, E. Pretoria:

Institute for Security Studies.

Rauch, J. and van der Spuy, E. 2006. Police reform in post-conflict Africa, Pretoria: Safety and Security Programme of the Institute for Democracy in South Africa. Retrieved from www.idasa.org.za

Reiner, R. 1992. The politics of the police, London: Harvester Wheatsheaf.

Reiss, A.J. Jr. and Bordua, D.J. 1967. "Environment and organization: A perspective on the police". In The police: Six sociological essays, Edited by: Bordua, D.J. New York: Wiley.

Rhodes, R. 2006. "The sour laws of network governance". In Fighting crime together: The challenges of policing and security networks, Edited by: Fleming, J. and Wood, J. 15-34. Sydney: University of New South Wales Press.

Roche, D. 2002. Restorative justice and the regulatory state in South African townships. British Journal of Criminology, 42: 514-533.

Schärf, W. and Nina, D., eds. 2001. The other law: Non-state ordering in South Africa, Johannesburg: Juta.

Sekoana, T. 2007. Police, security firms align forces. Bua News, Retrieved from http://www.southafrica.info/what_happening/news/security-110507.htm

Simon, J. 2007. Governing through crime: How the war on crime transformed American democracy and created a culture of fear, Oxford: Oxford University Press.

Singh, A. 1997 . 'Changing the soul of the nation'? South Africa's national crime prevention strategy. Paper presented at the British Criminology Conference, Queens University. Belfast. July 15-19, 1997

Singh, A. and Kempa, M. 2007. "Reflections on the study of private policing cultures: Early leads and key themes". In Police occupational culture: New debates and directions, Edited by: O'Neill, M., Marks, M. and Singh, A. London: Elsevier.

Skogan, W. 2007. Leadership from bottom to top: Chicago's model for community policing. Paper presented at Apex Scotland Annual Lecture, Signet Library. Glasgow. September 11, 2007

Smit, B. and Botha, C. 1990. Democracy and policing: An introduction to paradox. Acta Criminologica, 3(1): 36-45. 
Van Zyl Smit, D. and van der Spuy, E. 2004. "Importing criminological ideas in a new democracy: Recent South African experiences". In Criminal justice and political cultures: National and international dimensions of crime control, Edited by: Newburn, T. and Sparks, R. 184-208. Cullompton, Devon: Willan.

Wood, J. 2006a. "Dark networks, bright networks and the place of the police". In Fighting crime together: The challenge of policing and security networks, Edited by: Fleming, J. and Wood, J. Sydney: University of New South Wales Press.

Wood, J. 2006b. "Research and innovation in the field of security: A nodal governance view". In Democracy, security and the governance of security, Edited by: Wood, J. and Dupont, B. 217-241. Cambridge: Cambridge University Press.

Zedner, L. 2006. Policing before and after the police: The historical antecedents of contemporary crime control. British Journal of Criminology, 46(1): 78-97. 